F.?. COLLEG

\title{
FEE 1971
}

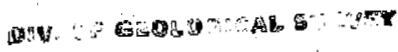

UNITED STATES DEPARTMENT OF THE INTERIOR

453

GEOLOGICAL SURVEY

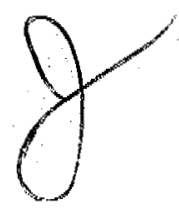

\section{TRANSLATION OF 1964 RUSSIAN CORRELATIONS \\ BETWEEN WRANGEL ISLAND AND NORTHERN AIAASKA \\ edited by}

I. L. Tallleur

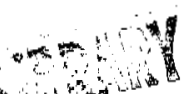

Open-file report

1971

This report has not been edited or reviewed for conformity with U.S. Geological Survey standards of nomenclature 


\author{
Translation of 1964 Russian correlations \\ between Wrangel Island and northern Alaska
}

Edited by

I. L. Tailleur

The following article by N. A. Bogdanov and G. M. Tilman was translated by members of the U.S. Geological Survey during an in-house training course in Russian in 1965. The translation has been useful internally and apparently fairly represents the original because Bogdanov has not disapproved its public release.

The article is valuable to Amerasian Arctic geology: It is the first detalled note of the similarity between coeval rocks across the Chukchi Sea; and it provides a workable description of the bedrock of Wrange1 Island. The English translation will permit more of its value to be realized in the rapidly growing investigations of the Arctic.

IH. C. Berg, W. P. Brosgé, A. B. Ford, E. H. Lathram, T. P. Miller, W. W. Patton, Jr., and I. L. Tallleur 
Similarities in the development of the Palaeozoic structure of Wrangel Island and the western part of the Brooks Range (Alaska)

N. A. Bogdanov and C. M. Tilman

(Reference: Bogdanov, N. A., and Tilman, S. M., 1964: Obshchie cherty razvitila paleozolskikh structur ostrova Vrangelia 1 zapadnoi chasti khrebta Bruksa (Allaska), p. 219-230 and Soveshchanie po Problem Tektoniki, Moscow, 1963, Skladchatye oblasti Evrazii; materlaly. Moskva, Nauka, $375 \mathrm{p}$.

The extreme northern Eurasian and American continents are separated by narrow Bering Strait and the shallow shelves of the Chukotsk and Bering Seas. This is the only place where the western and eastern parts of the Pacific ring are aligned. Therefore any information about the geology of the northeastern Chukotsk region and adjacent Islands, and the northwestern part of Alaska are of great interest, Insofar as they bring nearer the exposure of the tectonic connections between the large scale structural elements of the two continents.

Publications devoted to description of the tectonic fabric of the Chukotsk fold zone (Obruchev, 19.34, 1940; Popov, 1958; Pushcharovsky, 1960 2 ; Tilman, 1962) and Alaska (Smith, 1939; Payne, 1951; Miller, Payne and Gryc, 1961) and in addition generalizations on Soviet and partly foreign Arctic tectonics (Shatsky, 1935; Sax, 1958; Pushcharovsky, 1960; Bogdanov, 1963) expressed the most general theory about the unity of the tectonic history in the Paleozoic and Mesozoic of these two regions.

More detalled material on these regions has not been published until recently so a satisfactory interpretation of concrete structural correlation between the two regions has not been feasible. Published descriptions of Paleozolc tectonics were especially weak.

In recent years, special studies of the stratigraphy and structure of the upper Paleozoic deposits within the Brooks Range of northern Alaska have been made by Bowsher and Dutro in the Endicott Mountains and by Sable and Dutro in the De Long Mountains. In the summer of 1962 the authors together with geologists S. G. Byalobjesky and A. D. Chehov, accomplished similar investigations on Wrangel Island, located 400-500 km along the westward projection of the Brooks Range chain. The new data on the upper Paleozoic from our work on Wrangel Island and the literature sources on Alaska permit outlining the tectonic development of these two regions.

\section{Wrangel Island}

The first specifically geologic study of Wrangel Island was made by L. V. Gromov in 1935-1936. Based on this work, he concluded that deposits of Upper Paleozolc (Carboniferous-Lower Permian) and possibly, of Lower Paleozoic (Cambrian-Silurian) age were widespread and were overlain by upper Triassic rocks on the southern coast. Later (1939-1940), Gromov and M. T. Kurushina continued the investigation and distinguished lower, middle, and upper Paleozoic rocks in the Central Mountains. V. M. Basov, A. A. Gorbunov, and other members of the trust "Arctic prospector" (sic) expedition (Lobanov, 1957), studied the Paleozoic rocks in greater detail. Based on their fleld observations, these workers distinguished Cambro-Silurian, Devonian and Lower Permlan rocks in the Paleozoic sequence. 
In 1960, Gorodinsky made a geologic reconnalssance of the Island. He considered that carbonate? sediments of Lower Carboniferous age occur disconformably on formations conditionally dated as pre-Cambrian and are overlain disconformably by a sandy-shaly series of Upper Triassic (Karnian and Norian stages) age.

Study of the Paleozoic sections has led the present authors to several conclusions different from those of their predecessors.

In the Central Mountains, in the central part of Wrangel Island, they have described a continuous section of upper Devonian(?) (1) and Mississippian

(1) Previously, Gorodinsky, based only on the degree of metamorphism, erroneously regarded these units as Proterozoic.

deposits transgressively and discordantly overlain by Lower Permian and, possibly, Pennsylvanian rocks as well as by the upper Trlassic deposits.

The basal section of the Paleozoic deposits is comprised of units of the Berry suite, a thick assemblage of contrasting 1ithic types. The exposed lower part of the Berry suite consists of dark-gray and greenish-gray, clay and 1imy clay slate, about 1,000-1,200 m thick. The slate is succeeded upwards by greenish-gray and brownish-red foliated arkosic sandstone. Subordinate interbeds and lenses of green- and red-colored slate, conglomerate, grit, and gray and dark gray cherty limestone are present. The thickness of this part of the section aggregates 1,400-1,500 $\mathrm{m}$.

Capping the Berry suite is an assemblage of varicolored rocks consisting of schistose sandstone, slate, grit, and conglomerate, not more than 300$350 \mathrm{~m}$ thick. Pebbles in the conglomerates consist of cherty rocks, rarely of quartz, usually white or yellow, and more rarely of granitic rocks. Sporadic pebbles of sandstone and slate are 1ithologically very similar to the rocks in the lower part of the suite. The total exposed thickness of the Berry sulte is about $3,000 \mathrm{~m}$. The age remains uncertain in that no fossils were collected from these rocks. As the suite is conformably overlain by carbonate deposits with a Lower Carboniferous fauna, as established by us on the upper Hishchikov River, we provistonally assigned the sulte an upper Devonian age.

Mississippian (Lower Carboniferous) formations (sic) are the most widespread on the Island. They form most all of the west coast and continue as well to the margins of the Northern Mountains and onto the spurs of the Central Mountains. Deposits of this age represent a thick sequence of terrigenous-carbonate rocks. The base of the section is exposed only in the southern part of the Central Mountains. Here, gray and greenish-yellow dolomite, with alternating lenses (3-5 m) of gypsum in the basal part and with greenish-gray clay shale interbeds above, lies without apparent angular discordance upon a varicolored zone of the upper Berry suite. The total thickness of this lower zone is about $100 \mathrm{~m}$.

Upwards in the section, the dolomite grades to dark-gray, almost black subbituminous crinoidal limestone alternating with interbeds of black phyllitized clay and liny calcareous shale. In limestone from this section we collected numerous bryozoa identified by 0 . M. Lazutky as: Fenestella cf. donaica Leb. var. major Nikif., F. cf. beschevensiformis Nikif., F. ex. gr. equinodata Nikif., F. aff. polyporata Phill., Pinnatopora sp., Reteporidra sp., Polypora sp., Septopora sp. Romborpora sp., Nikiforovella sp., 
Sulcoretepora sp. and brachiopods (identified by V. N. Krestornikov and H. S. Rozman). Productus (Pustula) ex. gr. pustulosis Phill., Spirifer ex. gr. blsulcatus Sow., Reticularia sp.

This fauna, together with the brachlopods and corals collected in 1960 by Gorodinsky, date the enclosing rocks as Mississippian.

In the northern part of the island, the facies in the upper zones change somewhat. Here the rocks are less variable, consisting chiefly of dolomitized limestone alternating with numerous interbeds of bryozoan and crinoidal limestone and substantially fewer interbeds of shale. Fossils collected in this region are identical to the fauna of the Central Mountains.

To the south and north of the Central Mountains, the limestone and dolomite are overlain by dark gray and black phyllitized shale with rare interbeds of clayey limestone. The total thickness is about $800 \mathrm{~m}$. The shale is succeeded in turn by Iight-gray and yellowish gray thick-bedded crinoidal and algal limestone about 300 m thick.

The total thickness of Mississippian deposits on Wrangel Island reaches 2,900-3,000 $\mathrm{m}$ and the aggregate thickness of mid-Paleozoic deposits is about $5,500-6,000 \mathrm{~m}$.

Tectonic features of the mid-Paleozoic deposits are similar. In general, Wrangel Island consists of an anticlinorium with the axial trace latitudinally along the central Mountains and steepened to the north,

Rocks of the Berry suite form a rather steep homocline, broken by numerous longltudinal and diagonal and by fewer transverse faults. The homocline is complicated locally by oblique and plunging folds no wider than 50-60 m (Mamontov River basin). In the northern Central Mountains, the homocline is cut by a large-scale, wide fault and by a parallel system of faults of less displacement arrayed to the south. This fault, along with the smaller fractures, controls a serles of quartz veins and stockworks, dikes of gabbro-dlabase and porphyry, small massifs of hypabyssal and intrusive rocks: granite porphyry, granodiorite porphyry and plagloclase granite.

In the lower and middle part of the Berry suite, lit-par-lit injected gabbro-diabase sills are widespread, and have been folded with the rocks enclosing them. In the vicinity of fault dislocations, the rocks are intensely disturbed or even stood on end. A zone of fractured and mylonitized rock trace along the principal fault for more than $20 \mathrm{~km}$. The width of this zone reaches tens of meter. The fault referred to represents a steep (about $40-50^{\circ}$ ) thrust itself, along which rocks of the Berry sulte have been thrust upon lower Carboniferous (Mississippian) deposits. Tectonic overlap (duplication) is observed close beside faults on the northern slopes of the Central Mountains.

The fault under consideration plays an important part in the structure of the Island. It separates the southern half of the Island from the northern and into regions in which the tectonic style is essentially different. In the northern part of the Island, Mississippian deposits occur in a series of large and small brachy-synclines and domal anticlines, complicated on the limbs by numerous smaller folds with dips not over $40^{\circ}$. Many of the small folds are restricted(?) to diagonal fractures. The plane of folding in the northern Island is gentle, approaching horizontal, whereas in the south it is considerably steeper. 
Fold dislocations of the Mississippian deposits in the southern part of the Central Mountains are not distinguishable from those that characterize the Berry suite.

On the western coast and also in the southwestern and southeastern parts of the Island, mid-Paleozoic rocks are in contact with Pennsylvanian?lower Permian deposits or directly with Upper Trlassic. The contact is Irregular nearly everywhere with numerous steep pockets and pocket-shaped channels. It is indicative of transgressive overlap of Upper Paleozoic and Upper Triassic rocks onto different horizons of the Mississippian exposed by deep erosion.

The Pennsylvantan?-Permian deposits consist of varicolored or dark gray sandstone and shale as well as gray limestone. Aggregate thickness of the section approaches $1,500 \mathrm{~m}$. They form rounded synclines superposed on folded mid-Paleozoic rocks. The dips on the limbs of these synclines seldom exceed $30^{\circ}$. Sandstone and shale of the upper Triassic are dislocated more weakly. In the south part of the Island, they form a monocline dipping $10-25^{\circ}$. On the west coast the homocline is complicated by small undulating folds symmetrical in cross-section. On the east coast, steeply dipping to overturned dips are observed among gently dipping rocks, usually along faults. The axial planes of overturned acute-angled? folds almost always dip north. Upper Triassic deposits are apparently involved in the structure on the northern limb of the anticlinorium. The axis of it plunges under the De Long Straits.

To summarize the above information, it must be sald that the epoch of primary folding of the mid-Paleozoic rocks on Wrangel Island took place in middle and partially upper Carboniferous tine, 1.e. in that period of tectonic development when the geosyncline in the Kolimsky-Alaska province was closed (Pushcharovsky, 1960; Tilman, 1962; Bogdanov, 1963).

Along trends to the west and to the east, structures on Wrangel Island project into the Eastern Siberian and Chukchi Seas. Their continuation to the south seems to be in the anticlinal uplifts of the Chukotsk orogen (Kuulcko and others), and to the east - folded structures of the western Brooks Range, Alaska.

\section{Brooks Range}

Mid-Paleozoic deposits comprise the north flank of the mountainous structure of the Brooks Range. The best and most complete of them were studied and described in the Endicott and De Long Mountains, in the western and northwestern parts of the Range. Here were distinguished deposits of Upper Devonian and Lower Carboniferous age.

In the Endicott Mountains, in the area of Shainin Lake, according to the data of A. Bowsher and T. Dutro (Bowsher, Dutro, 1957), the highest deposits in the basal section are composed of shales, among which are found strata of quartz sandstones, (the whole section) commonly more than 470 meters thick. In the shales the brachiopod Cyrtospirifer sp. was collected. Above this they (the shales) are gradually replaced by strata separated under the name "Kanayut Conglomerate." In the lower part of this section, these beds are composed of coarse-pebble conglomerate up to 400 meters thick, which conformably overlies a 340-meters band of medium-sized 
pebble conglomerate sequence with beds of massive coarse-grained sandstones. Siliceous pebbles are contained in this conglomerate. The upper strata represent a band of alternating orthoquartzites, varicolored sandstones changing their color from green and greenish-gray to red, and medium-sized pebble conglomerate with a total thickness of around 280 meters. Fragments of the flora Archeopteris were found in this part of the Kanayut Conglomerate section. The general thickness of the Kanayut Conglomerate is around 1,100 m.

In the regions to the west in the De Long Mountains, the upper Devonian section undergoes a considerable facies change. In this region in the Kugururok River, E. Sable and T. Dutro (Sable, Dutro, 1961) found deposits of this same age in the Kugururok series (sic). In the lower, exposed part of the series (sic) is exposed a band of shale and coarse and medium-grained sandstone, among which occur poorly interbedded grit and fine pebble conglomerate and limestone. They give a general thickness of 130 meters. Above this section shale and sandstone changes to gray, fine-grained limestone, among which occur, interbedded with the limestones, fine-sized pebble conglomerates, sandstones, and shales up to $185 \mathrm{~m}$ thick. In the limestone were collected indeterminable solitary corals Thamopora sp., Gypidula sp., Atrypa sp., Euryzone sp., Strobeus? sp. and cephalopods, which according to $T$. Dutro, permit dating of the age in the containing units as the Frasntan (stage). The upper section of the Kugururok serles (sic) forms massive and medium bedded gray dolomite, in sequence with rare interbedded pelitomorphic and sandy limestone. The thickness of the dolomite is around 100-110 m. In the Kugururok River valley, in the dolomites were noticed poorly preserved brachlopods of the Famennian (stage), similar with Cyrtiopsis? and Cyrtosplrifer. The general thickness of the Kugururok series (sic) is around $410-420 \mathrm{~m}$.

On the North Slope in the De Long Mountains the dolomite facies changes to shale and limestone with a variable thickness of around $50 \mathrm{~m}$. In these were discovered Schizophoria sp., Productella sp., Leiorhynehus cf., L. seversoni McLaren, Pugnoides sp., Stropheura? sp. Cyrtospirifer? sp., (Clelothyridina) sp., Aviculopecten? sp. Cyrtoclymenia Dinichthys hertzeri Newberry and orthoceratites. These fossils, according to T. Dutro, allow an age to be taken into consideration for the shale and average(?) limestone. So, as in the De Long Mountains, nowhere has it been successful in one place to describe the section of upper Devonian deposition, the thickness of it can be placed only highly approximately. According to the data of E. Sable and $T$. Dutro there is apparently not less than $600-700 \mathrm{~m}$ visible here. Everywhere within the boundarles of the Brooks Range deposits of upper Devonian are overlain by rocks of Lower Carboniferous age. At the base of the Lower Carboniferous a break is traced and an insignificant unconformity.

In the Endicott Mountains, A. Bowsher and T. Dutro (Bowsher, Dutro, 1957) Included deposits of the Lower Carboniferous in the Lisbourne Group, which in turn is separated into three formations: Kayak Shale ${ }^{(1)}$, Wachsmuth Limestone, and Alapah Limestone.

(1) Bowsher and Dutro (1957) originally did not include the Kayak Shale In the contents of the Lisbourne Group. However, in later work, these shales were correlated with the lower part of the Lisbourne Group in other districts (Sable, Dutro, 1961). 
Wachsmuth and Alapah Limestones. The lower part of these formations (Kayak Shale) consists of black clayey shales, in which are intercalated sandstones and sandy, mottled, marly limestones. The thickness of the Kayak Shale is 300 meters. The formation contains the following faunal zones: Scalarituba sp., Cryptoblastus aff.; C. pisum (Meek and Worthen), Leptaena analoga (Phillips)?, characteristic of the basal Tournaisian stage of the Early Carboniferous.

The Wachsmuth Iimestone overlies the Kayak Shale with negligible unconformity. The Wachsmuth is made up of alternating clayey crinoidal and siliceous limestones and dolomites that are commonly dark sulfur in color, and medium bedded. Chert occurs in the upper part of the formation. According to Bowsher and Dutro, a cross-section of the formation reveals the following paleontological zones: "Zaphrentis" konincki s. 1. (M. Edwards and Haime), Spirifer tenuicostatus (Ha11), Brachythyris suborbicularis (Hall), characteristic of the upper part of the Tournaisian. The thickness of the formation is about 380 - 400 meters.

The base of the Alapah Limestone rests on an erosion surface, but the formation overlies the Wachsmuth with negligible unconformity. A section of the Alapah shows that it consists of alternating white and light-gray coarsely crystalline argillaceous limestones, among which are intercalated thin-bedded and fissile varleties of black siliceous slates and conglomeratic limestones with chert pebbles. Bowsher and Dutro (1957) describe seven faunal zones in the Alapah Limestone (from the base upwards): Naticopsis howi (Dawson), Lithostrotion aff. L. asiaticum (Yabe and Hayasaka), Eumetria costata (Hall), Sciophyllum lambarti (Harker and McLaren), Goniatites crenistria (Phililps), Lithostrotionella? sp. (small corallites), and Gigantoproductus striato-sulcatus (Schwetzoff); these belong to the Visean and Namurian stages of the Lower Carboniferous. The thickness of the Alapah is about 300 meters. The total observed thickness of the Lisburne Group is 1,000 meters.

In the western part of the Brooks Range, in the De Long Mountains and on the west coast of Alaska, in the valley of the Kukpuk River, and at Cape Thompson, are widely distributed examples of Lower Carboniferous rocks which here, as in the Endicott Mountains, form the Lisburne Group. According to Sable and Dutro (1961), the most complete and best-studied sections of Iimestone in the De Long Mountains are on the slopes of Tupik Mountain, where the base of the Lower Carboniferous section is the Utukok Formation. The lower part of this formation is made up of about 425 meters dark-gray and brownish-gray limestones that alternate with layers of limy shales, siltstones, and quartzitic sandstones. In the upper half of the basal section the Utukok Formation changes to sandy limestones and limy and clayey shales. The thickness of this member is 450 meters. In both lower and upper members the fossil assemblages are: Fenestella sp., Polypora sp., Schuchertella sp., Leptaena analoga (Phillips), Echinoconchus? sp., Spirifer aff. S. osagensis Swallow, S. aff. S. rowlet Weller, Brachythyris sp., Composita aff. C. humilis Girty, Puñctospirifer aff. P.? solidirostri (White), and straparollus (Eumophalus) sp., characteristic of the basal Lower Carboniferous. The average thickness of the formation is 875 meters. 
The overlying Kogruk Formation is represented by dark-gray massive and medium-bedded sandstones and siliceous (cherty?) 11mestones that are Intercalated with sparse layers of chert, claystones, and limy and clayey shales. In the limestones are: Ieptaena analoga (Phillips), Chonetes sp., Orthotetes sp., Pustula sp., "Dictyoclostus" cf. "D." viminalis (White), Iinoproductus sp., Spirifer sp., Brachythyris of. suborbicularis (Hall), and Dimegelasma sp., which date the beds as the Visean Stage of the Lower Carboniferous. The thickness of the Kogruk Formation ranges from 175 to 350 meters.

The Tupik Formation is at the top of the Lower Carboniferous section in the De Long Mountains. It is composed of a sequence of alternating yellowish-gray massive to medium-bedded 1imestones and dark-green banded cherts (cherty slates). The limestones carry a fauna including: Orbiculoides sp., Chonetes sp., Productella sp., Leiorhynchus? sp., Crurithyris sp., and Raonnoceras rangifer Gordon, which, according to Dutro, characterizes the top of the Lower Carboniferous. The exposed thickness of the Tupik Formation is about 40 meters. The average total thickness of the Lower Carboniferous deposits in the De Long Mountains is 1,000 - 1,400 meters. The formations can be traced westward to the northwestern coast of Alaska, where they are exposed at Capes. Thompson and Lisburne.

Lower Carboniferous and Upper Devonian deposits form the northern limb of the Brooks anticlinorium in northern Alaska, where they are folded Into long, narrow, latitudinal anticlines that strike northwest. Commonly these structures are $10-15$ kilometers long, and do not exceed $5-8$ kilometers wide. Dips in the limbs range from $25-30^{\circ}$ to $40-50^{\circ}$, and in the cores the beds are almost horizontal. The folds on the northern Iimb of the Brooks anticlinorium are cut by a complicated system of east-west faults. Some of these faults, as established by Bowsher and Dutro (1957), seem to be overthrusts, along which northward movement of $10-15$ kilometers took place. To the north, in the basin of the Colville River, these structures are overlain with strong angular unconformity by formations of Permian, Triassic, Jurassic and, in some places, Lower Cretaceous age. These complete the sequence deposited in the Colville trough (geosyncline?).

\section{Comparison of Sections}

In a comparison of the middle Paleozoic deposits of these two regions one automatically turns considerable attention to their lithologic resemblances and to the similar sequence in the shift of the different facies complexes (fig. 1).

In both sections, Upper Devonian deposits are represented on the whole by terrigenous rocks. It is especlally interesting that on Wrangel Island as well as the Brooks Range, in the upper part of the section, an important role is played by sets and beds of conglomerate and gravel which are absent in sections of contemporaneous formations of the more southern regions of the Anyuy (tributary of Kolyma River) - Chukotsk zones and of Alaska, and are also absent on the islands of the Canadian Arctic and New Siberian archipelagoes. It is characteristic that in comparable regions pebbles in conglomerates consist of the same rocks - quartz, quartzites, siliceous formations, slates, etc. The great thickness of the Devonian section within 
Wrangel $I$.

Central Mts.

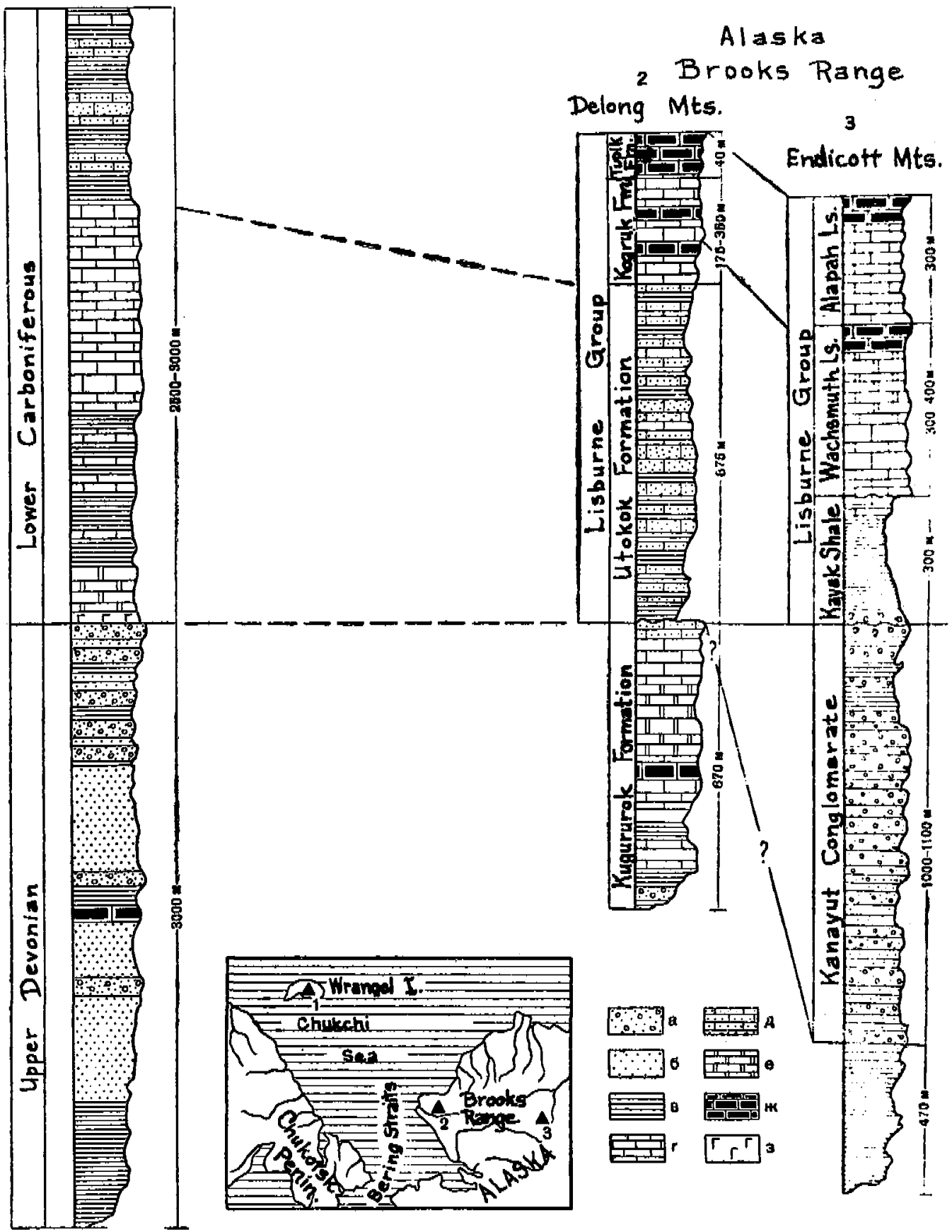

Fig. 1. Correlation of the sections of the upper Devonian and lower Carboniferous of Wrangel Island and the Brooks Range. Insert map shows locations of sampled sections (triangles).

Lithology: a--conglomerate, b--sandstone, c--shale, d--limestone, e--sandy limestone, f--dolomite, g--cherty limestone, h--gypsum. 
the limits of Wrangel Island (3,000 meters in comparison with 1,100 meters In the Brooks Range) may be explained, in our opinion, by the fact that in the first mentioned of these districts the Berry suite probably has a slightly greater stratigraphic range and may include the top strata of the Middle Devonian.

Lower Carboniferous formations on the north slope of Alaska and on Wrangel Island are represented on the whole by shallow water shelf facies. The limestones making up the big part of these sections, are, as a rule, crowded with debris of crinoid segments and also with bryozoans and algae. Within the limits of the Brooks Range, sandy limestones and limestones containing pebbles of siliceous rocks are encountered with the limestones. On Wrangel Island lenses of gypsum are present in the lower part of the section of deposits of this age. Without doing special comparative studies of fossils of these two regions it is difficult to make exact comparisons of the separate groups of sections. It is only possible to state the supposition that the rocks of the Lisburne Group of the Brooks Range are the stratigraphic analogs of the lower half of the section of Lower Carboniferous deposits of Wrangel Island. If such a comparison is true, then there is no doubt that the thickness of the Lower Carboniferous deposits of Wrangel Island is greater than the thickness of contemporaneous formations of the Brooks Range.

\section{Conclusions}

Thus, we come to the conclusion that, within the boundaries of the two regions described, miogeosynclinal flexures were depressed in a vast Kolyman-Alaskan region in the Middle Paleozoic epoch. The flexure located in the region of Wrangel Island was included in the Chikotsk-Polousnensk geosynclinal zone (Bogdanov, 1963) or the Chukotsk (T1lman, 1962); and the flexure of the Brooks Range was in the Franklin geosynclinal zone; these were continuous from west to east. These zones had many common traits for long epochs of geologic development, from the beginning of the Ordovician, and possibly of the Cambrian, up to Middle Carboniferous time. According to all information the territory of Wrangel Island and the Brooks Range are in the northernmost parts of the geosynclinal zones mentioned, which framed the hyperboreal platform (according to N. C. Shatsky, 1935) on the south, as is belleved by many investigators (Pushcharovsky, 1960 (2); Saks, 1958; Tilman, 1962; Payne, 1951; Martin, 1961). We stil1 do not have information about the first stages of the Paleozolc tectonic development of the flexures, which were located in the limits of Wrangel Island and on the northern slope of the Brooks Range, for in both cases the oldest Paleozoic deposits are represented by formations of the Upper (and possibly Middle) Devonian. Therefore we dwell only on the examination of the final stages of the formation of these flexures.

In the last half of Devonian time, as may be judged by the findings of R. Thorsteinson and E. Tozer (Thorsteinson, Tozer, 1960), L. Martin (Martin, 1961), P. (sic) Payne (Payne, 1951), U. M. Bichkov (1958), S. M. Tilman (1962), M. E. Gorodinsky (1963) and others, accumulation mainly of terrigenous sediments took place in the mlogeosynclinal flexures of the Franklin and Chukotsk-Polousnensk geosynclinal zones. In the 
southern and central parts of these, the sediments are as a rule represented by fine-grained varieties. Only within the boundaries of the Canadian Arctic Archipelago on Cornwallis Island are there present among them beds of conglomerate which, in the opinion of $E$. Thorsteinson (1958), represent fanglomerates. Payne (1951) mentioned that in Alaska the role of coarse-grained formations in the Devonian section increases in a northward direction.

Information received about the northwest Brooks Range and about Wrangel Island, as is obvious, confirms this point of view. The great thickness of Kanayut conglomerates in the Upper Devonian section of the Endicott Mountains and formations simflar to them in the upper part of the section of the Berry suite of Wrangel Island testify to the relatively abrupt change of fine clastic rocks to coarse clastic rocks in a northward direction. This is undoubtedly caused by the fact that the main region of deposition of terrigenous material was located to the north of the contemporary materials, i.e., in the limits of the North Frozen Ocean (Arctic. Ocean) (figure 2).

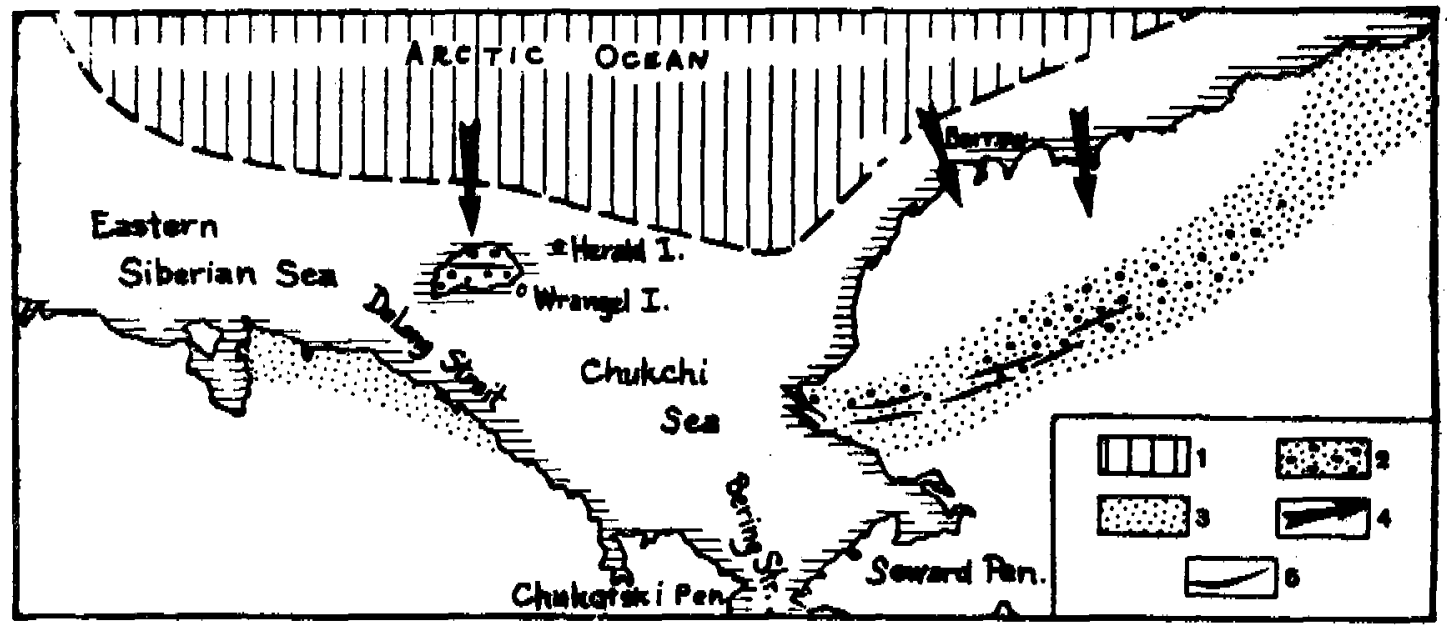

Fig. 2. Generalized map of Upper Devonian terrigenous (sedimentary rocks) of northern Chukchi and Alaska.

Explanation: 1--presumed source area ("far northern" platform), 2--conglomerates; 3--sandstones; 4--direction of transport of sedimentary materia1; 5--axes of fault troughs. 
The composition of pebbles and debris of terrigenous origin of Devonian age is of essential interest for apparent correlation between source and accumulation areas. From leading studies of the detrital rocks, it seems that quartz predominates in the latter environment along with rare shales of diverse types including siliceous, cherty types, and more rare eruptive rocks (Wrangel Island). Eruptive rocks and gneisses or other metamorphic rocks are absent in pebbles of the conglomerate. Pebbles are usually well rounded. It is necessary to think that such a content of detrital materials and its roundedness are explained if the location of the source area was at a considerable distance from the miogeosynclinal downwarp.

In the comparison of middle Paleozoic deposits of described areas, one important case stands out. As is indicated, in the De Long and Endicott Mountains, the Lisburne Group occurs as overlying transgressive deposits, and in places, with angular unconformity. On Wrangel Island, as seemed from our investigations, an angular unconformity is absent beneath the Carboniferous deposits. Nevertheless, the appearance of conglomerates and varicolored rocks high in the section of the Berry suite, and dolomite and gypsum in the lower Carboniferous deposits, is evidence of a wide drainage basin that preceded the transgressive seas again advancing at the beginning of the Carboniferous Period. This appearance, it seems, is best explained as a manifestation of general tectonic movements, although weak in places but extremely characteristic over considerable areas. Initial tectonic movement is localized at this time in the joint zone of the miogeosynclinal downwarp with the "far northern" platform.

Thus for the whole extent of the upper half of the Devonian Period, in epochs of strong differential movements, the "far northern" platform played the largest role in the tectonic development of the miogeosynclinal downwarp in the northern part of Alaska and the Chukch 1 Peninsula. Careful study has shown considerably smaller effects of sagging to the south in the early Carboniferous.

Within the described territory there occurred at this time exclusively shallow water sedimentation. The region, site of detrital material in Upper Devonian and Lower Carboniferous, was either completely submerged beneath sea level or represented by a group of separate islands of reduced relief. In any case, erosion (of it) of terrigenous detritus was considerably less(?) than in the preceding epochs. At the beginning of Lower Carboniferous, chiefly carbonate and argillaceous beds with abundant shell fauna were deposited in the rapidly sinking miogeosynclinal depression. At the end of Lower Carboniferous, simultaneously with uplift and cessation of sedimentation in the miogeosynclinal depression, there was a change In facies of the deposits.

Sandy limestone, saridstone, and variegated shales accumulated in the northern part of the Paleozolc miogeosyncline. Frequently in these rocks there occur pebbles of diverse cherts, similar to the pebbles of the Upper Devonian conglomerate. Apparently in this period of geologic history a region of erosion was located a short distance from the region of sedimentation. It is possible to explain the smaller amount of terrigenous rock by slight tectonic movement as compared with the late Devonian epoch. 
At the end of lower Carboniferous within all the wide Paleozoic Kolyma-Alaska region sedimentation stopped; it was replaced by general uplift and folding. Analysis of the morphology of fold structures attests to the fact that the intensity of dislocation of mid and upper Paleozoic deposits gradually diminishes in a northward direction. Thus in the Brooks Range folds (doubly plunging anticlines and synclines) reach $8-10 \mathrm{~km}$ in width and $10-20 \mathrm{~km}$ in length; dips on their limbs are generally $40^{\circ}-60^{\circ}$. Here there is widespread overthrusting. In the southern part of Wrangel Island similar structures are absent, although dip angles of the rocks remain approximately the same and the rocks as a rule dip to the south. In the northern part of the island Paleozoic formations are substantially flat. The rocks are crumpled Into small folds but the plane surface of folding is nearly horizontal.

And in northern Alaska and Chukotsk, as in other miogeosynclinal depressions of the Kolyma-Alaska region, intrusions of Paleozoic age are almost completely absent. On Wrangel Island are known in all only a few smal1 hypabyssal intrusives of granite porphyry, granosyenite (sic), and plagioclase granite (sic), and also dikes of gabbro-diabase and lamprophyre, the age of which are possibly upper Carboniferous. All of these intrusive bodies are confined to a zone of fractures which trends across the central part of the island and probably represents a purely local occurrence.

Thus the study of composition and morphology of the tectonic structures of middle and upper Paleozoic deposits of Wrangel Island and the north slope of the Brooks Range confirms earlier suppositions by Soviet and American geologists that in the development of these-geosynclinal forms in the eastern Arctic an essentlal influence was exerted by the ancient hypaboreal platform. In particular, the margin of this platform served as a source of abundant detrital material. Undoubtedly further study of Paleozoic and younger deposits on the northern edge of Chukotsk and Alaska will yield new more complete information on the character of the core (nucleus) of the hypaboreal platform (and?) on the development of structure in the folded regions. 